\title{
Penanggulangan Premanisme Di Kota Medan (Studi di Satuan Reskrim Polresta Medan)
}

\section{Treatment Of Premanism In Medan City (Study at the Medan Police Criminal Investigation Unit)}

\author{
Berlin Sinaga*, Triono Eddy \& T. Erwinsyahbana \\ Program Magister Ilmu Hukum, Universitas Muhammadiyah Sumatera Utara, Indonesia
}

Diterima:19 Agustus 2020; Direview: 17 September 2020; Disetujui: 14 Oktober 2020

*Email: berlinsinaga89@gmail.com

\begin{abstract}
Abstrak
Premanisme adalah kegiatan kelompok orang yang mendapatkan penghasilannya terutama dari pemerasan kelompok masyarakat lain serta menimbulkan keresahan masyarakat. Di Kota Medan sampai sekarang premanisme terus berkembang dan sangat merugikan masyarakat. Tujuan penelitian ini untuk mengkaji terkait faktor terjadinya premanisme di Kota Medan, upaya penanggulangannya, serta kendala yang dialami oleh pihak Satuan Reskrim Polresta Medan dalam menanggulangi tindakan premanisme. Penelitian yang dilakukan adalah penelitian yuridis empiris yang bersumber dari data primer dengan melakukan wawancara kepada AKP Heri Sofian yang menjabat sebagai Padal OPS Tim Pemburu Preman Satuan Reskrim Polresta Medan dan data sekunder dengan mengolah data dari bahan hukum primer, bahan hukum sekunder dan bahan hukum tersier. Hasil penelitian bahwa banyak faktor- faktor yang mempengaruhi terjadinya premanisme di Kota Medan baik dari dari sisi kriminologi ditemukan seseorang menjadi preman karena kurangnya pendidikan, malas bekerja dan munculnya pola pikir salah bahwa menjadi preman adalah suatu hal yang hebat dan patut dibanggakan, selain daripada itu faktor ekonomi juga mempengaruhi karena kemiskinan yang dialami si pelaku, terakhir ialah faktor lingkungan yang tidak baik sehingga membentuk seseorang untuk menjadi seorang preman.
\end{abstract}

Kata kunci: Preman, Kepolisian, Tindak Pidana, Kriminal.

\begin{abstract}
Thuggery is the activity of a group of people who earn their income mainly from extortion of other groups of people and cause public unrest. In Medan City until now thuggery continues to grow and is very detrimental to the community. The purpose of this study was to examine the factors associated with thuggery in Medan, the efforts to overcome them, and the obstacles experienced by the Medan Police Criminal Investigation Unit in overcoming thuggery acts. The research conducted was an empirical juridical research which was sourced from primary data by conducting interviews with AKP Heri Sofian who served as Padal OPS of the Medan Police Criminal Investigation Unit's Preman Hunting Team and secondary data by processing data from primary legal materials, secondary legal materials and tertiary legal materials. The results of the study show that there are many factors that influence the occurrence of thuggery in Medan, both in terms of criminology, it is found that someone becomes a thug due to lack of education, laziness to work and the emergence of a wrong mindset that being a thug is something great and should be proud of, apart from that the factors the economy also affects because of the poverty experienced by the perpetrator, the last is environmental factors that are not good so that they form a person to become a thug.
\end{abstract}

Keywords: Preman, Police, Crime, Crime.

How to Cite: Sinaga, B. Eddy, T. \& Erwinsyahbana (2020). Penanggulangan Premanisme Di Kota Medan (Studi di Satuan Reskrim Polresta Medan). Journal of Education, Humaniora and Social Sciences (JEHSS). 3(2): 333-341. 


\section{PENDAHULUAN}

Premanisme lahir dari kondisi sosial yang sangat buruk karena keterpurukan ekonomi, lilngkungan dan lingkungan kemiskinan yang akut plus rendahnya tingkat pendidikan di masyarakat. Berdasarkan aspek sosiologis maraknya praktiknya premanisme dalam lini kehidupan masyarakat juga ditengarangi oleh faktor tumbuh kembangnya serta struktur sosial dari seorang manusia. Tindakan premanisme yang terjadi sering diindikasikan sebagai aktivitas dari sekelompok orang yang tidak memiliki pekerjaan (Nugroho, 2017). Menurut (Kunarto, 2000), berpendapat bahwa menjadi seorang preman berarti telah mendeklarasi posisinya di masyarakat sebagai orang yang tidak memiliki pekerjaan serta keterampilan yang memadai.

Fenomena premanisme merupakan salah saatu khazanah sosiologis pergulatan kehidupan yang terjadi di perkotaan ketika kerasnya hidup memaksa semua orang untuk menekuni bidang apapun manakalah cara yang dirasa wajar dirasa sulit untuk mencari sumber pendapatan demi kebuguhan dapur agar terus terpenuhi, hal ini dapat diindikasikan bahwa alasan klasik desakan ekonomi serta pola survivalitas di perkotaan yang kian sengit, maka memunculkan preman sebagai aktualisasi aktir ekonomi informasi di perkotaan (Raharjo, 2000).

Pelaku premanisme telah memanfaatkan beberapa jawara lokal untuk melakukan tindakan premanisme tingkat bahwa yang pada umumnya melakukan kejahatan jalanan (street crime) seperti pencurian dengan pencurian dengan ancaman kekerasan (Pasal 363 KUHP), pemerasan (Pasal 368 KUHP), bahkan penganiayaan yang tentunya dapat mengganggu ketertiban umum serta menimbulkan keresahan di masyarakat. Kehidupan dan perilaku masayrakat harus diatur oleh hukum agar pelaksanaan kehidupan bermasyarakat dapat berjalan dengan tertib dan aman. Dengan demikian, dalam hidup bermasyarakat manusia terdapat dua aspek, yaitu eksistensi merujuk pada keberadaanya yang berbeda dangan makhluk hidup lainnya.

Berdasarkan dengan amanat UUD 1945 maka tugas aparat Negara penegak hukum yaitu Kepolisian Republik Indonesia (Polri) yang didasarkan UU No. 2 Tahun 2002 tentang Kepolisian Negara Republik Indonesia. Melalui data yang diperoleh dari Satuan Reskrim Polresta Medan didapati data dari jumlah premanisme yang pernah terjadi di sekitar wilayah Kota Medan pada titik-titik tertentu dari ata itu diperoleh total pelaku premanisme ialah 975 orang sepanjang tahun 2017-2019. Rincian 77 orang sampai ke Pengadilan, 898 Pembinaan di Kepolisian Resor Kota Besar Medan.

Berdasarkan hal tersebut maka menarik untuk dikaji permasalahan penaganan premanisme oleh Lembaga Kepolisian RI berdasarkan tugas dan kewenangan yang terdapat dalam UU No. 2 Tahun 2002 tentang Kepolisian NKRI khususnya di Kota Medan. Preman pada umumnya tidak disidangkan melalui pengadilan, kecuali perbuatan preman tersebut telah menimbulkan tindak pidana. Preman yang disidangkan misalnya akan diputus pidana penjara, pidana kurungan ataupun pidana denda.

\section{METODE PENELITIAN}

Jenis Penelitian ini menggunakan penelitian hukum normatif, dengan pendekatan terhadap sistem hukum. Sifat dari penelitian ini adalah deskriptif artinya dalam penelitian ini hanya ingin menggambarkan upaya-upaya pihak kepolisian dalam menghadapi tindakan premanisme di kota Medan Penelitian yang dilakukan adalah penelitian yuridis empiris yang bersumber dari data primer dengan melakukan wawancara kepada AKP Heri Sofian yang menjabat sebagai Padal OPS Tim Pemburu Preman Satuan Reskrim Polresta Medan dan data sekunder dengan mengolah data dari bahan hukum primer, bahan hukum sekunder dan bahan hukum tersier.

\section{HASIL DAN PEMBAHASAN}

\section{Faktor Penyebab Tindakan Premanisme Di Kota Medan}

Masyarakat (society) dapat dimaknai sebagai arena perebutan kepentingan antar kelompok (class), di mana masing-masing ingin agar kepentingannya menjadi referensi bagi masyarakat. Dalam perebutan kepentingan ini telah menyebabkan tidak terakomodirnya kepentingan individu atau kelompok dalam struktur masyarakat 
tertentu. Kesenjangan dan ketidaksesuaian ini memunculkan protes dan ketidakpuasan dan kemudian berlanjut pada dislokasi sosial individu atau kelompok tertentu di dalam sebuah struktur masyarakat. Dislokasi ini bisa diartikan sebagai tersingkirnya kepentingan sebuah kelompok yang kemudian memicu timbulnya praktik-praktik premanisme di masyarakat. Praktik premanisme tersebut tidak hanya terjadi di kalangan masyarakat bawah, namun juga merambah kalangan masyarakat atas yang notabene didominasi oleh para kaum intelektual.

Menurut Ediwarman, seorang Preman timbul karena sifat Individu yang diperoleh sebagai warisan dari orang tuanya, keadaan badaniah, kelamin umur, intelek, temperamen kesehatan dan minuman keras (Ediwarman, 2004). Para tokoh genetika misalnya berargumen bahwa kecenderungan untuk melakukan tindakan kekerasan atau agresifitas pada situasi tertentu kemungkinan dapat diwariskan. Sarjana lainnya tertarik pada pengaruh hormon, ketidaknormalan kromosom, kerusakan otak dan sebagainya terhadap tingkah laku kriminal (Santoso, 2010). Terdapat beberapa faktor yang mempengaruhi orang melakukan praktek premanisme khususnya di Kota Medan. Berikut data prktek premanisme yang pernah terjadi di Kota Medan di beberapa wilayah dari Tahun 2017-2019: Dari Titik Rawan Paling Sering Terjadi Tindakan Premanisme Di Kota Medan Tahun 2017-2019 (Wawancaa oleh Satuan Reskrim Polresta Medan)

\begin{tabular}{|c|c|c|c|}
\hline No. & Nama Tempat & Jumlah Preman & Keterangan \\
\hline 1. & Terminal Amplas & 103 orang & 13 sampai ke Pengadilan selebihnya pembinaan \\
\hline 2. & Jl. Merak Jingga & 30 orang & 2 sampai ke Pengadilan Selebihnya pembinaan \\
\hline 3. & Simpang Pos & 25 orang & Pembinaan \\
\hline 4. & Kawasan Industri Medan & 71 orang & 6 sampai ke Pengadilan Selebihnya pembinaan \\
\hline 5. & Sepanjang Jl. Padang Bulan & 87 orang & 7 sampai ke Pengadilan Selebihnya pembinaan \\
\hline 6. & Terminal Pinang Baris & 89 orang & 5 sampai ke Pengadilan Selebihnya pembinaan \\
\hline 7. & Jl. Semarang & 42 orang & 3 sampai ke Pengadilan Selebihnya pembinaan \\
\hline 8. & Pusat Pasar/Medan Mall & 100 orang & 15 sampai ke Pengadilan Selebihnya pembinaan \\
\hline 9. & Loket Sepanjang Jl. SM. Raja & 45 orang & Pembinaan \\
\hline 10. & Jl. Asia & 38 orang & 1 sampai ke Pengadilan Selebihnya pembinaan \\
\hline 11. & Komplek MMTC & 53 orang & 5 sampai ke Pengadilan Selebihnya pembinaan \\
\hline 12. & Pengangkutan Jl. H.Anif & 42 orang & 4 sampai ke Pengadilan Selebihnya pembinaan \\
\hline 13. & Teladan & 105 orang & 10 sampai ke Pengadilan selebihnya pembinaan \\
\hline 14. & Tembung Pasar 12 & 95 orang & 6 sampai ke Pengadilan Selebihnya pembinaan \\
\hline 15. & Sepanjang Jl. Gatsu & 50 orang & 1 sampai ke Pengadilan Selebihnya pembinaan \\
\hline
\end{tabular}

Dari data tersebut ada total 975 orang pelaku premanisme pada tahun 2017-2019, dimana 77 orang sampai ke Penfgadilan dan 898 orang Pembinaan di Kepolisian Resor Kota Besar Mdan. Keterangan Tabel: 1) Nama Tempat: menunjukkan beberapa wilayah di Kota Medan yang sering terjadi Tindakan Premanisme; 2) Jumlah Preman: menunjukkan kuantitas para pelaku premanisme di berbagai wilayah di Kota Medan (dari hasil wawancara tidak ada data pertahun, melainkan data yang mencakup 2017-2019, akan tetapi pihak Polresta menyampaikan tiap tahunnya jumlah pelaku premanisme terus meningkat); 3) Keterangan: menununjukkan tindakan yang dilakukan kepada para pelaku premanisme, ada yang sampai pada tingkat Pengadilan dan ada yang hanya sampai tahap pembinaan di Polresta Medan. 
Penjelasan dari hasil wawancara oleh pihak Satuan Reskrim Polresta tersebut ialah bahwa itu merupakan titik-titik tempat yang paling sering terjadi tindakan premanisme, walaupun ada tempat-tempat lain yang pernah terjadi premanisme namun kuantitas orang-orang yang melakukan premanisme tersebut terbilang kecil. Oleh sebab itu pihak Satuan Reskrim Polresta Medan hanya memberikan titik tempat yang sepanjang Tahun 2017-2019 sering terjadi kegiatan premanisme.

\section{Faktor-Faktor Penyebab Terjadinya Pelaku Premanisme Di Kota Medan.}

Kejahatan merupakan suatu fenomena yang kompleks yang dapat dipahami dari berbagai sisi yang berbeda. Itu sebabnya dalam keseharian kita dapat menangkap berbagai komentar tentang suatu peristiwa kejahatan yang berbeda satu dengan yang lain. Dalam pengalaman kita ternyata tak mudah untuk memahami kejahatan itu sendiri (Santoso, 2010). Oleh karena premanisme termasuk dalam katagori tindakan kejahatan, maka dapatlah pula premanisme untuk mencari penyebabnya dilihat dari sudut pandang kriminalisme. Karakteristik kriminologi dapat melihat kejahatan itu terjadi dari berbagai sudut pandang, sehingga didapati penyebab utama dari kejahatan (premanisme) itu dan pada akhirnya dapat diambil solusi atasnya. Kri inologi merupakan ilmu pengetahuan yng bertujuan menyelidiki gejala kejahatann seluasluasnya.

Premanisme termasuk perbuatan kejahatan yang dapat menimbulkan perbuatan tindak pidana lainnya seperti pemalakan, pemukuilan, kekeraan yang dapat mengakibatkan kematian seperti dalam Pasal 365 KUHP. Dengan demikian tindakan premanisme yang terjadi dim Kota Medan ini dipandang dari sisi kriminologimerupakan peerbuatan immoral yang melanggar kesusilaan akan tetapi harus dilihat lebih mendalam terkait terjadinya kejahatan premanisme itu. Sejak alhir setipa orang membawa sifat-sofat yang baik dan buruk di smaping perlengkapan fisik dan psikisnya. Secara kodrati sifat-sifat tersebut menuntut untuk dapat dikembangkan. Untuk berkembang diperlukan fakor-faktor lain, baik dari diirnya (internal) maupun dari luar (eksternal) sebagai penunjang. Kedua faktor ini secara timbal balik saling mempengaruhi individu dan dapat terlihat dari tingkah lakunya.

Jikalau sifat buruk berkembang dengan baik melebihi sifat baiknya, akan tampak tingkah laku yang tidak wajar. Ketidakwajaran itu karena adanya batasan tingkah laku yang dibutuhkan oleh kehidupan sosial. Batasan-batasan tingkah laku manusia dalam kehidupan sosial diwujudkan sebagai norma-norma pedoman hidup. Penyimpangan dari pedoman hidup dengan ketidakwajaran bertingkahlaku, seorang individu akan menimbulkan akibat-akibat yang dapat dirasakan, baik oleh individu itu sendiri sebagai penyebab maupun oleh lingkungan baik keluarga, sekolah dan masyarakat (Akhdhinat, 2011). Hal-hal yang demikian pulalah yang dapat mempengaruhi sifat ataupun perbuatan immoral yang dapat dilakukan oleh masyarakat, tidak terlepas kepada masyarkat Kota Medan.

Apabila disoalkan tentang sifat hakekat dari perbuatan immoral terlihat bahwa ada dua sudut pandangan. Subyektif, jika dipandang dari sudut orangnya, adalah perbuatan yang bertentangan dengan kesusilaan. Obyektif, jika dipandang dari sudut masyarakat, adalah merugikan masyarakat. Penyelidikan mengenai hal ini oleh sosiologi khusuusnya ethnologi membuktikan, bahwa immoral berarti: anti sosial dipandang dari sudut masyarakat. Golongan utilitaris yang mengira bahwa kesusilaan dapat diterangkan berdasarkan kegunaannya bagi perseroangan, adalah salah, tetapi pendapatnya menjadi betul jika perkataan perseorangan diganti dengan masyarakat, kegunaan bagi masyarakat iniliah yang dituju oleh peraturanperaturan kesusilaan. Dalam beberapa hal manusia mempunyai perasaan yang yang tajam terhadap hal yang merugikan masyarakat, masa lampu aru-baru ini (seerti juga masa yang telah lebih lama lampau) mengajarkan pada kita dengan tegas sekali bahwa rasa ini, kaena pengaruh dari para pemimpin yang tidak mempunyai kesusilaan, dalam suatu bangsa dapat hilang untuk

wwt http://mahesainstitute.web.id/ojs2/index.php/jehss

mahesainstitut@gmail.com

336 
sementara dengan cara yang menyedihkan. Karena besarnya kekuasaan masyarakat atas perseorangan yang sedang bertumbuh maka biasanya diterimanya oleh aturan-aturan kesusilaan yang berlaku (Bonger, 1995).

Perbuatan immoral oleh sebab itu adalah perbuatan anti-sosial, yang dirasakan demikian pula. Tidak ada suatu perbuatan yang a priori dapat dianggap perseimmoril atau dianggap sebagai kejahatan, jadi tidak ada perbuatan yang menurut kodratnya jahat, ini tergantung dari keadaan masyarakat. Tetapi beberapa perbuatan begitu bertentangan dengan tiap masyarakat, hingga hampir selalu dilarang (seperti mencuri, karena sifatnya yang merugikan). Masyarakat selalu berubah dan dalam taraf sekarang malahan cepat sekali. Karena itu terjadi perubahanperubahan besar dalam kesusilaan, perubahan-perubahan itu juga terasa dalam hukum pidana. Hal ini baru terjadi lama kelamaan, ketegangan antara kesusilaan yang berubah dengan cepat dan hukum pidana yang agak tetap sehingga dapat menjadi sangat besar. Maka dari itu kejahatan premanisme merupakan pernuatan immoral, tapi hanya merupakan sebagian daripadanya saja.

Faktanya sepanjang tahun 2019 ini diketahui bahwa angka kemiskinan di Kota Medan masih sangat tinggi. Angka kemiskinan di Kota Medan cukup tinggi, yakni sekitar 463.000 jiwa atau dengan persentase 18\% dari jumlah penduduk yang mencapai 2,6 juta (Syahputra, 2019). Badan Pusat Statistik (BPS) Sumatra Utara (Sumut) mencatat tingkat pengangguran terbuka (TPT) per Februari 2019 ada di angka 5,56\% dari tingkat partisipasi angkatan kerja di Sumut. Meski TPT turun dibandingkan Februari 2018 sebesar 5,59\%, namun jumlah pengangguran di Sumut justru meningkat menjadi 414.000 orang atau naik 11.000 orang dibandingkan Februari 2018 sebanyak 403.000 orang.

Bertambahnya jumlah pengangguran karena terjadi peningkatan jumlah angkatan kerja sebanyak 224.000 orang menjadi 7,45 juta di Februari 2019. Seperti diketahui, komponen pembentuk angkatan kerja adalah penduduk yang bekerja dan pengangguran. Jadi penduduk Sumut yang bekerja pada Februari 2019 sebanyak 7,04 juta dan menganggur 414.000 orang. Kepala BPS Sumut, Syech Suhaimi, mengatakan, dilihat dari tempat tinggalnya, TPT di perkotaaan cenderung lebih tinggi dibanding di pedesaan. Salah satu pengangguran terbanyak di Sumatera Utara ialah berada di Kota Medan, hal itu dikarenakan banyak orang di berbagai daerah sekitar Kota Medan datang ke Kota Medan untuk mencari pekerjaan namun tidak mendapatkannya. Tingkat kemiskinan dan tingkat pengangguran di Kota Medan itu menunjukkan bahwa banyaknya orang di Kota Medan yang kekuarangan ekonomi untuk memenuhi kebutuhannya sehari-hari.

Teori kriminologi tentu disini juga harus dijadikan sebagai pegangan untuk menelaah faktor kejahatan premanisme, akan tetapi faktor yang dilihat disini ialah melalui faktor kemampuan ekonomi masyarakat, yang hal itu datang dari dua arah pertama kekurangan ekonomi yang berasal dari masyarakat itu sendiri yang mempunyai kebutuhan yang berlebih tidak dibarengi dengan kemampuan yang, serta yang kedua datang dari pihak pemerintah yang kurang memberikan lahan pekerjaan bagi para pemuda ataupun masyarakat yang ingin bekerja guna memenuhi kebutuhan ekonominya sehari-hari. Hal karena kebutuhan ekonomi tersebut tidak terpenuhi dengan tidak adanya pekerjaan bagi masyarakat tersebut, maka muncullah pemikiran-pemikiran beberapa masyarakat untuk menjadi premans guna mendapatkan ekonomi yang dibutuhkan, namun dengan cara yang salah. Sebagai akibatnya cara yang salah itu dikategorikan sebagai tindakan kejahatan yang dapat berakibat sanksi hukum pidana terhadapnya.

Atas dasar itu dikaitkan dengan hukum yang berlaku, faktor yang berasal dari masalah ekonomi ini menjadi suatu problematika di dalam kehi dupan bermasyarakat. Dengan kata lain hukum-hukum yang di bentuk oleh pemerintahan sebagian tidak menguntungkan masyarakat, sehingga masyarakat sulit untuk mendapatkan pekerjaan dan pada akhirnya

霞http://mahesainstitute.web.id/ojs2/index.php/jehss 
menganggur. Oleh sebab itu pilihan terakhir masyarakat yang menganggur tadi untuk memenuhi kebutuhan ekonominya memilih jalan sebagai pelaku premanisme.

Faktor terakhir yang melatarbelakangi seseorang melakukan tindakan premanisme di Kota Medan ialah dari sisi pengaruh lingkungan tempat pelaku tersebut hidup, beraktivitas atapun tinggal. Faktor pengaruh lingkungan sekitar menjadi salah satu faktor pokok utama dari tindakan-tindakan premanisme yang ada. Karena kejahatan itu datang kadangkala bukan karena pelaku ingin melakukannya, atau karena ada kebutuhan yang terdesak. Namun, kejahatan itu bisa datang dari ajaran-ajaran serta pola pikir jahat yang diajarkan oleh lingkungan sekitarnya. Sehingga psikologi seseorang yang tinggal di dalam lingkungan masyarakat tersebut berubah menjadi suatu tindakan premanisme (wawancara dengan AKP Heri Sofian, 2019).

Faktor lingkungan yang mempengaruhi tindakan seseorang melakukan premanisme didasari pada berubahnya pola pikir masyarakat atas pengaruhi lingkungan, sehingga ini berhubungan erat dengan psikologi yang terbentuk dalam lingkungan masyarakat, secara ilmu kejahatan hal itu dikenal juga dengan psikologi criminal. Psikologi kriminal ialah ilmu pengetahuan tentang kejahatan dipandang dari sudut ilmu jiwa. Penyelidikan mengenai jiwa dari penjahat dapat semata-mata ditujukan kepada kepribadian perseorang (umpama jika dibutuhkan untuk member penerangan kepada hakim). Akan tetapi dapat juga untuk menyusun tipologi (golongan-golongan) penjahat. Penyelidikan mengenai gejala- gejala yang tampak pada kejahatan yang dialkukan oleh suatu kelompok atau massa (orang banyak) sebagian juga termasuk dalam psikologi (sosial) kriminil, di mana disebabkan oleh perbuatan tersebut dalam pergaulan hidup, tak boleh dilupakan. Akhirnya ilmu jiwa dari orang-orang lain di Pengadilan (saksi, hakim, pembela dan lain-lain) serta tentang pengakuan (Bonger, 1995).

\section{Upaya Aparat Kepolisian Pada Satuan Reskrim Polresta Medan Dalam Penanggulangan Tindakan Premanisme}

Terdapat beberapa upaya Kepolsian Satuan Reskrim Polresta Medan dalam penanggulangan tindakan premanisme. Upaya-upaya tersebut baik mulai dari upaya perbaikan sistem di internal kepolisian sendiri, upaya persuasif pembinaan kepada pelaku premanisme melibatkan masyarakat dan instansi berwenang, serta upaya dalam bentuk tindakan tegas yaitu upaya paksa (wawancara dengan AKP Heri Sofian, 2019).

Kriminalitas tidak dapat dihilangkan dari muka bumi ini, tetapi dapat dikurangi melalui tindakan-tindakan pencegahan berikut (Akhdiat dan Marliani, 2011): 1) Hukuman. Selama ini hukuman (punishment) menjadi sarana utama untuk membuat jera pelaku kriminal. Pendekatan berhavioristik ini tampaknya masih cocok untuk dijalankan dalam mengatasi masalah kriminal. Akan tetapi, diperlukan kondisi tertentu, misalnya konsisten, fairness, terbuka, dan tepat waktunya; 2) Penghilang model melalui tayangan. Media massa itu ibarat dua sisi mata pisau. Jika ditayangkan, masyarakat tidak mampu mengantisipasi kejahatan tersebut; 3) Membatasi kesempatan, seseorang bisa mencegah terjadinnya tindakan kriminal dengan membatasi munculnya kesempatan untuk mencuri. Kalau pencuri akan melaui pintu masuk dan kita sudah menguncinya, cara itu termasuk mengurangi kesempatan untuk mencuri; 4) Jaga diri, misalnya dnegan keterampilan bela diri dan beberapa persiapan lain sebelum terjadinya tindak kriminal bisa dilakukan oleh warga masyarakat.

Upaya kepolisian dalam memberantas atau lebih sederhananya menanggulangi fenomena tindak pidana premanisme di dalam lingkungan masyarakat khususnya masyarakat Kota Medan merupakan salah satu bentuk pelayanan public yang diberikan pihak Kepolisian kepada masyarakat. Yang hal itu juga diamanahkan oleh Undang-Undang Nomor 2 Tahun 2002 tentang Kepolisian Negara Republik Indonesia.

Pelayanan publik adalah pintu gerbang emas yang akan menghantarkan polisi dengan citra humanis. Untuk menghantar masyarakat pada kesejahteraan umum, maka pintu gerbang

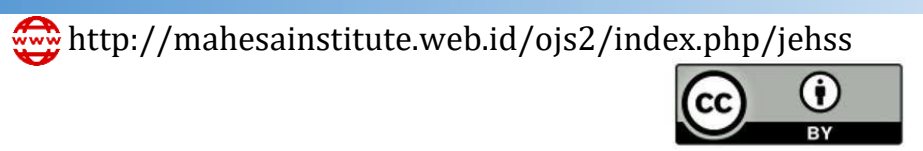

Nmahesainstitut@gmail.com

338 
emas (pelayanan public) harus berlandaskan instrument standard pelayanan yang menjamin hak warga Negara dan inovasi pelayanan secara terus-menerus (Busyro, 2019; Simanjuntak et al., 2010; Rusdi et al., 2020; Sigiro et al., 2020).

Kepolisian Satuan Reskrim Polresta Medan mengungkapkan bahwa uapya penaggulangan premanisme di Kota Medan dimulai dari pihak kepolisian sendiri baik dari perbaikan su ber daya manusia yang lebih berdedikasi, serta pemenuhan sarana dan prasarana kepada anggota yang bertugas. Salah satu upaya nyata yang dibentuk oleh pihak Kepolisian Satuan Reskrim Polresta Medan ialah dengan membentuk Tim Pemburu Preman dan meningkatkan patroli secara berkala yang dilakukan dititik-titik rawan dan diwaktu-waktu tertentu saat pelaku premanisme beraksi (wawancara dengan AKP Heri Sofian, 2019).

Pembentukan Satuan Tim Pemburu Preman di wilayah Polresta Medan merupakan upaya nyata dari internal Kepolisian untuk menanggulangi tindakan premanisme di Kota Medan, sehingga preman-preman di tempat adanya patrol tim yang dimaksud tidak dapat merajalela sesuka hatinya. Pembentukan Tim Pemburu Preman oleh Satuan Reskrim Polresta Medan itu berdasarkan Maklumat Kepala Kepolisan Daerah Sumatera Utara Nomor: Mak/02/VIII/2018, yang isinya sebagai berikut:

Dalam rangka menciptakan keamanan dan ketertiban di wilayah Provinsi Sumatera Utara, maka Kepolisian Daerah Sumatera Utara memandang perlu mengeluarkan maklumat sebagai berikut: 1) Premanisme adalah kegiatan kelompok orang yang mendapatkan penghasilannya terutama dari pemerasan kelompok masyarakat lain serta menimbulkan keresahan masyarakat; 2) Setiap orang secara melawan hukum memaksa orang lain supaya melakukan, tidak melakukan atau membiarkan sesuatu, dengan memakai kekerasan, atau dengan ancaman kekerasan, dapat dipersangkakan melakukan tindak pidana sebagaimana diatur dalam Pasal 335 Kitab Undang-Undang Hukum Pidana, dengan ancaman pidana penjara paling lama 1 (satu) tahun; 3) Setiap orang yang memaksa dan meminta sesuatu dari orang lain dengan kekerasan atau ancaman kekerasan untuk memberikan sesuatu barang kepunyaan orang itu atau orang lain, maka orang tersebut dapat dipersangkakan melakukan tindak pidana pemerasan sebagaiman diatur dalam Pasal 368 ayat (1) Kitab Undang-Undang Hukum Pidana, dengan ancaman pidana penjara paling lama 9 (Sembilan) tahun; 4) Setiap orang atau kelompok yang melakukan ancaman pencemaran nama baik dengan lisan maupun tulisan atau dnegan ancaman akan membuka rahaisa, memaksa seseorang supaya memberikan barang sesuatu, yang seluruhnya atau sebagian kepunyaannya atau orang lain, atau suoaya memberikan hutang maupun menghapus piutang, maka orang tersebut dapat dipersangkakan melakukan tindak pidana pengancaman sebagaiamana diatur dalam pasal 369 KUHP dengan ancaman pidana paling lama 4 (empat) tahun; 5) Setiap orang yang dengan sengaja dan tanpa hak mengirimkan informasi dan atau dokumen elektrinik yang berisikan ancaman atau menakut-nakuti secara pribadi dapat dipersangkakan melakukan Pasal 29 UU No. 11/2008 tentang Informasi dan Transaksi Elektonik dengan ancaman pidana penjara paling lama 4 (empat) tahun sebagaimana dimaksud dalam Pasal 45 B UU No. 19/2016.

Maklumat tersebut langsung ditandatangi oleh Kepala Kepolisian Daerah Sumatera Utara pada tanggal 28 Agustus 2018. Melalui aturan khusus dari kebijakan polisi tersebut tampaklah jelas bahwa upaya nyata dari pihak kepolisian khususnya Kepolisian Satuan Reskrim Polresta Medan dalam menanggulangi dan menangani tindakan premanisme di masyarakat Kota Medan. Sehingga diharapkan dapat meminimalisir tindakan premanisme tersebut. Keseriusan pihak kepolisian itu merupakan bentuk upaya kepolisian dari tubuh internalnya, dengan begitu juga dapat membangun citra baik polisi di mata masyarakat. Karena tidak dipungkiri dari dulu sampai sekarang masih ada stigma-stigma tidak baik dari masyarakat kepada polisi. Maka tentu sebaiknya sebelum melakukan upaya lain dalam melakukan penanggulangan kejahatan harus 
terlebih dahulu memperbaiki pada bagian internal kepolisian, seperti halnya memperbaiki citra polisi di mata masyarakat, khususnya masyarakat Kota Medan.

Undang-undang memberikan kewenangan kepada pejabat tertentu untuk melakukan pembatasan terhadap kebebasan dan kemerdekaan seseorang dalam berbagai bentuk kegiatan. Pembatasan kebebasan dan kemerdekaan ini ada yang bersifat sementara, ada pula yang bersifat terhitung lama, bergantung pada bagimana aturan hukum menentukan dan mengaturnya. Pembatasan kebebasan dan kemerdekaan ini merupakan suatu tindakan atau upaya paksa yang harus dilakukan dalam rangka mengikuti perintah undang-undang. Kitab Undang- Undang Hukum pidana telah menentukan adanya beberapa tindakan atau upaya paksa yang dapat dilakukan sehubungan dengan terjadinya tindak pidana yang dilakukan oleh seseorang (Muhammad, 2007).

Sebelum dijatuhinnya hukuman dalam bentuk sanksi pidana, pihak Kepolisian melalui perintah undang-undang dapat melakukan upaya paksa terlebih dahulu kepada para pelaku tindak pidana/kejahatan seperti premanisme ini. Upaya paksa kepada pelaku premanisme ini berbagai macam baik itu penangkapan, penahanan, penggeledahan, maupun penyitaan.

\section{SIMPULAN}

Faktor yang menjadi menjadi penyebab tindakan premanisme di Kota Medan dari segi kriminologi yaitu kurangnya pendiidkan di masyarakat, malas beekrja serta kebuuthan ekonomi yang sangat kurang. Kurangnya kemmapuan dan skill yang dimiliki masyarakat hingga mecari jalan pintas untuk mendapatkan uang dengan menjadi preman. Uapaya aparat kepolisian pada Satuan Polresta Kota Medan dalam melkaukan penaggulangan tindak premanisme ialah dengan meingkatkan kualitas SDA di Kepolisan, meberikan sarana dan prasarana yang baik serta memadai bagi petugas yang bertugas. Membentuk Tim Pemburu Preman di wilayah Polresta Medan berdasarkan Maklumat Kapolda Sumut No. Mak/02/VIII/2018 serta melakukan melakukan setiap penindakan kepada pelaku premanisme sesuai dengan Standar Operasional Prosedur (SOP) yang telah ditetapkan dan terakhir bergerak berdasarkan legal standing/kewenangan

\section{DAFTAR PUSTAKA}

Akhdhiat, H, dan Marliani. R., (2011). Psikologi Hukum. Bandung: CV Pustaka Setia

Bonger, W.A., (1995). Pengantar Tentang Kriminologi. Jakarta: Pustaka Sarjana

Busyro, M. (2019). Tinjauan Kriminologis Terhadap Preman yang Melakukan Kejahatan (Studi Kasus Polsek Batangtoru). DOKTRINA: JOURNAL OF LAW, 2(2), 99-116. doi:https://doi.org/10.31289/doktrina.v2i2.2614

Ediwarman, (2004). Monograf Metodologi Penelitian Hukum (Panduan Penulisan Tesis dan Disertasi). Medan

Kunarto. (2000). Kejahatan Berdimensi Baru. Jakarta: Cipta Manunggal

Muhammad, R. (2007). Hukum Acara Pidana Kontemporer. Bandung: PT. Citra Aditya Bakti.

Nugroho, A.S. (2017). Tinjauan Kriminologis Tindak Premanisme Oleh Pengamen Di Simpang Lima Kota Semarang, Jurnal Hukum Diponegoro (Diponegoro Law Journal), Program Studi Ilmu Hukum, Fakultas Hukum Universitas Diponegoro, Volume 6, Nomor 1,

Rahardjo, S. (2000). Ilmu Hukum. Bandung: Citra Aditya Bakti.

Rusdi, R., Mulyadi, M., \& Afan, I. (2020). Analisis Yuridis Penghentian Penyidikan terhadap Tindak Pidana Korupsi Ditreskrimsus Polda Sumatera Utara. Journal of Education, Humaniora and Social Sciences (JEHSS), 2(3), 720-734. doi:https://doi.org/10.34007/jehss.v2i3.78

Santoso, T., dan Zulfa, E.A. (2010). Kriminologi. Jakarta: PT.Raja Grafindo

Sigiro, D., Suhaidi, S., \& Affan, I. (2020). Perlindungan Hukum Bagi Korban Hubungan Seksual Sedarah (Studi Pada Unit Perlindungan Perempuan Dan Anak SATReskrim Polrestabes Medan). Journal of 
Vol 3, No. 2, Desember 2020: 333 -341

Education, Humaniora and Social Sciences (JEHSS), 3(1), 200-212. doi:https://doi.org/10.34007/jehss.v3i1.261

Simanjuntak, M., Januari S., dan Isnaini, (2010), Peran Polri dalam Penyidikan Tindak Pidana Kekerasan Seksual dalam Rumah Tangga (Studi di Unit Perlindungan Perempuan dan Anak Sat Reskrim Polresta Tebing Tinggi), Mercatoria, 3 (2):102-116

Syahputra, A. (2019), Tekan Angka Kemiskinan, Pemko Medan Hanya Berharap Bantuan Kemensos. http://www.medanbisnisdaily .com/news /online/ $\quad \mathrm{read} / 2019 / 02 / 17 / 66579 /$ tekan_angka_kemiskinan_pemko_medan_hanya_berharap_bantuan_kemensos/, diakses tanggal 03 Oktober 2019, pukul 06.35 WIB.

UUD 1945

UU No. 2 Tahun 2002 tentang Kepolisian Negara Republik Indonesia.

Maklumat Kepala Kepolisan Daerah Sumatera Utara Nomor: Mak/02/VIII/2018 